\title{
MINI-CUTTINGS ROOTING OF Sequoia sempervirens AT DIFFERENT IBA CONCENTRATIONS AND CLONES
}

\author{
Mariane de Oliveira Pereira ${ }^{1 *}$, Alessandro Camargo Ângelo ${ }^{2}$, Marcio Carlos Navroski ${ }^{1}$, Luciana Magda de \\ Oliveira $^{1}$, Dionéia Felippe ${ }^{1}$, Carolina Moraes ${ }^{1}$
${ }^{1}$ Universidade do Estado de Santa Catarina (UDESC), Departamento de Engenharia Florestal, Lages, Santa Catarina, Brasil- *maripereira.florestal@gmail.com, marcio.navroski@udesc.br luciana.oliveira@udesc.br, dioneia.felippe@gmail.com, carolina.moraes1@edu.udesc.br
${ }^{2}$ Universidade Federal do Paraná (UFPR), Programa de Pós-graduação em Engenharia Florestal, Curitiba, Paraná, Brasil- alessandrocangelo@gmail.com

Received for publication: 29/10/2018 - Accepted for publication: 21/10/2019

\begin{abstract}
Resumo
Enraizamento de miniestacas de Sequoia sempervirens em diferentes clones e concentrações de AIB. Sequoia é uma espécie que proporciona grandes volumes de madeira, é resistente à decomposição e tem a produção de mudas por miniestaquia como uma alternativa viável. O objetivo do trabalho foi avaliar o enraizamento de miniestacas de diferentes clones de Sequoia sempervirens e posterior emprego de distintas concentrações de AIB em clones com baixo enraizamento adventício. Foram utilizadas miniestacas de diferentes clones, oriundas de minijardim clonal. No experimento com regulador de crescimento utilizaram-se diferentes concentrações de AIB (de $0 \mathrm{mg} \mathrm{L}^{-1}$ a $3000 \mathrm{mg} \mathrm{L}^{-1}$ ). O material foi colocado para enraizar em estufim e avaliado aos 90 dias. Todos os experimentos foram instalados em delineamento inteiramente casualizado, com posterior avaliação da sobrevivência (\%), miniestacas com calos (\%), miniestacas enraizadas (\%) e número de raízes (somente no experimento com diferentes concentrações de AIB). No primeiro experimento a sobrevivência das miniestacas foi alta (próximo a 95\%) e o enraizamento apresentou grande variação entre os clones (22,8 a 100\%). No segundo experimento, utilizando-se clones com enraizamento, anteriormente avaliado abaixo de 50\%, submetidos à aplicação de AIB, observou-se alta sobrevivência $(88,1$ a 99,4\%). Os clones apresentaram respostas variadas entre si, mas com melhora no enraizamento utilizando-se regulador de crescimento.

Palavras-chave: propagação vegetativa, regulador de crescimento, AIB, raízes.
\end{abstract}

\begin{abstract}
Sequoia is a species that provides large volumes of wood, is resistant to decomposition and has seedling production by mini-cutting as a viable alternative. The aim of this work was to evaluate the rooting of minicuttings of different clones of Sequoia sempervirens and subsequent use of different concentrations of IBA in clones with low adventitious rooting. Mini-cuttings of different clones were used, from clonal mini-garden. In the experiment with the growth regulator, different concentrations of IBA (from $0 \mathrm{mg} \mathrm{L}^{-1}$ to $3000 \mathrm{mg} \mathrm{L}^{-1}$ ) were used. The material was placed to be rooted in a mini-tunnels and evaluate at 90 days. All experiments were installed in a completely randomized design, with a subsequent evaluation of survival (\%), mini-cuttings with calluses (\%), mini-cuttings rooted $(\%)$ and number of roots (only in the experiment with different concentrations of IBA). In the first experiment, the survival of mini-cuttings was high (close to 95\%) and rooting showed great variation among the clones (22.8 to 100\%). In the second experiment, using clones that previously presented rooting less than $50 \%$, submitted to IBA application, high survival ( 88.1 to $99.4 \%$ ) was observed. The clones presented different responses among themselves, but with improve in the rooting using growth regulator.

Keywords: vegetative propagation, growth regulator, IBA, root.
\end{abstract}

\section{INTRODUCTION}

Sequoia sempervirens (D. Don) Endl.), is a conifer native to the west coast of the state of California and the southwest coast of the state of Oregon in the United States, corresponds to a well-known species, mainly because it is one of the highest, reaching more than 100 meters in ideal conditions of growth. It is a species used when there is a need for wood resistant to decomposition (OLSON et al., 1990). The tree is highly valuable, not only for ornamental purposes but also for industrial purposes, due to its rather vigorous growth. The species is rarely attacked by disease or insects and is resistant to strong winds and other adverse weather conditions. Seed germination is highly variable, presenting many empty seeds and with malformed or infected embryos with several

FLORESTA, Curitiba, PR, v. 50, n. 2, p. 1279 - 1286, abr/jun 2020.

Pereira, M. O. et.al.

ISSN eletrônico 1982-4688 
parasites. Like most forest species, seed propagation is predominant for the species, although vegetative propagation through root shoots or lateral sprouts also occurs (KORBAN; SUL, 2007).

Vegetative propagation was used to produce sequoia seedlings (LUNA, 2008) by cuttings, but few largescale that work in this sense have been reported in the literature (OLSON et al., 1990). For species that present seasonality in the production and storage difficulty of the seeds, mini-cutting is an alternative. By means of this technique, it is possible to form a clonal bank in a greenhouse, with a supply of diversified material for the production of seedlings aiming at the conservation of the species, besides allowing the selection of matrices with superior phenotypic characteristics for commercial production, as wood quality for the production of wood (OLIVEIRA et al., 2016).

The mini-cutting provides increases in rooting, in addition to favoring the development of a better quality root system for vigor, uniformity and volume, which positively reflects the survival and performance of the clone in the field (OLIVEIRA et al., 2012). However, it is important to know the factors that affect root formation, directly related to the success of cuttings production.

Some of the main factors involved in the rooting of mini-cutting are the hormonal balance, genetic constitution of the plant (potential and genetic variability within the species), endogenous level of inhibitors, nutritional conditions, propagation/youthfulness effect of propagule, season is collected, abiotic factors (temperature, light, humidity), substrate quality and the use of growth regulators. Regarding growth regulators, auxins were usually, considered as the main inducers of adventitious rooting, especially in difficult rooting species (DIAS et al., 2012). Among the most used, indole butyric acid (IBA) is used because of its efficiency, stability and lower toxicity over a wide concentration range. The sequoia cuttings respond favorably to the hormonal treatment (NAVROSKI et al., 2015). As the maturation effect of the donor plant of the species increases, the auxin concentrations increase (up to a certain limit) so that there is a maximization in the success in rooting (LUNA, 2008).

Considering that the clonal effect and the application of exogenous auxin present high importance in the clonal propagation, it was expected to find substantial differences between the tested clones, mainly due to the high number of genetic materials. For low-rooting clones without the use of growth regulator, it was expected that their use may increase root formation. In this context, we aim to evaluate the rooting of mini-cuttings of different clones Sequoia sempervirens and the subsequent use of different concentrations of IBA in clones with low adventitious rooting.

\section{MATERIALS AND METHODS}

As propagule sources for mini-cuttings were select from sequoia matrices (located in Sao Francisco de Paula, Rio Grande do Sul state, Brazil) of approximately 40 years of age, propagated by the conventional cutting process, 120 days after partial or complete annealing of the matrix tree. The material was collected from the parent trees and transported to the Forest Nursery located in Lages, Santa Catarina state, Brazil. After that, cuttings with a size of $10.0 \pm 2 \mathrm{~cm}$ of length and $0.7 \pm 2 \mathrm{~cm}$ of diameter containing a pair of acicular leaves reduced to $50 \%$ of the leaf area and treated with $6.000 \mathrm{mg} \mathrm{L}^{-1}$ of indole-3-butyric acid (IBA). Then, they were inserted in tubes $\left(180 \mathrm{~cm}^{-}\right.$ $\left.{ }^{3}\right)$ containing vermiculite of medium granulometry and commercial substrate $(1: 1 \mathrm{v} / \mathrm{v})$ and arranged in a minitunnel for rooting. The mini-tunnel is a structure located under the shadehouse and with the following dimensions: $8.0 \times 1.20 \times 0.9 \mathrm{~m}$ (length $\mathrm{x}$ width $\mathrm{x}$ height).

After cutting, five-month-old rooted cuttings were acclimatizing in a shade house for 30 days, then transferred to greenhouse to complete the acclimation for another 30 days until it the seedlings reaches $20 \mathrm{~cm}$ in height. Subsequently, were transferred to pots with 5L vases filled with peat and pine bark-based commercial substrate $(50 \%)$ and medium-sized vermiculite $(50 \%)$. Fifteen days after the installation, the time necessary to adapt the seedlings to the system, the apex of the cuttings the main bud was cut at a height of $10 \mathrm{~cm}( \pm 2 \mathrm{~cm})$, forming the mini-stumps for the establishment of the clonal mini-garden. Monthly, for four months, pruning of the mini-stumps was carried out.

The nutrient solution used in the clonal mini-garden was the base of the commercial fertilizer composed of $10 \% \mathrm{~N}$ (water soluble); $42 \% \mathrm{P}_{2} \mathrm{O}_{5}$ (water soluble); $10 \% \mathrm{~K}_{2} \mathrm{O}$ (water soluble); $0.6 \% \mathrm{Mg} ; 0.1 \% \mathrm{Fe}$ and $0.02 \mathrm{Br}$. Fertigation was done twice a week, with each mini-stump receiving $50 \mathrm{ml}$ of solution composed by diluting 1.5 grams of the fertilizer per liter of water. After the period of formation of the mini-stumps, the sprouts were collect to perform the experiments.

\section{Mini-cutting of different clones and application of IBA}

The first experiment consisted of the rooting of mini-cuttings of different clones kept in a clonal minigarden system. Sixteen treatments (clones) were used: A100, A113, A115, A116, A117, A126, A127, A130, A131, 
A133, A135, A136, A138, A140, A227 e A228). A completely randomized design was used, with 10 replicates of 10 stakes each. No growth regulator was used for this experiment.

With the clones that low rooting $(<50 \%)$, a second experiment was realized, using different concentrations of IBA. The first factor was composed of 4 clones (A100, A117, A126 and A138) and the second factor was IBA concentrations $\left(0,1000,2000\right.$ and $\left.3000 \mathrm{mg} \mathrm{L}^{-1}\right)$. Eight replications of 10 mini-cuttings each used; the design was completely randomized in a two-factorial scheme.

\section{Mini-cutting and growing conditions}

From each clone, mini-cuttings were prepared whit 8 to 10 centimeters in length, the basal portion being bevel cut and the upper portion being incised transversely, a pair of a pair of acicular sheets being cut in half. In the first experiment, there was no use of growth regulator. In the second experiment, the cuttings were immersed in hydroalcoholic solution, with the base of the cuttings remaining in contact with the solution for a period of 15 seconds. After preparation, the mini-cuttings were arrange to be rooted in $180 \mathrm{~cm}^{3}$ polypropylene tubes containing vermiculite of medium granulometry and commercial substrate $(1: 1 \mathrm{v} / \mathrm{v})$ with the addition of $6 \mathrm{~g} \mathrm{~L}^{-1}$ of Osmocote ${ }^{\circledR}$, where it was made the insertion of approximately $2 \mathrm{~cm}$ of the base of the mini-cutting in the substrate.

The commercial substrate for plants, according to the manufacturer, is composed of peat, expanded vermiculite, pine bark and charcoal. The chemical and physical characteristics, after analysis of the substrate, are as follows: $\mathrm{pH}=6.6$; electrical conductivity $=0.13 \mathrm{mScm}^{-1}$; wet density $=450.8 \mathrm{~kg} \mathrm{~m}^{-3}$; dry density $=302.7 \mathrm{~kg} \mathrm{~m}^{-}$ 3; current humidity $=32.8(\%)$; total porosity $=72.2(\%)$; aeration space $=17.0(\%)$; readily available water $=12.2$ $(\%)$; buffer water $=2.4(\%)$; remaining water $=40.5(\%)$; CRA10 - water holding capacity at $10 \mathrm{~cm}=55.1$; CRA50 $=42.9$ and CRA100 $=40.5$. The physical and chemical characterization of the substrate was Laboratory of Substrates of the Department of Horticulture and Forestry of the Federal University of Rio Grande do Sul.

The mini-cuttings were a condition in mini-tunnel (structure presenting $8.0 \mathrm{~m}$ long $\times 1.20 \mathrm{~m}$ wide $\times 0.9$ $\mathrm{m}$ high). The temperature inside the mini-tunnel generally ranges between $20-32{ }^{\circ} \mathrm{C}$ and relative humidity of the air remains above $80 \%$, and irrigation was performed by micro-sprinkler for 5 minutes, 5 times a day. The minicuttings remained in this condition for 90 days, at which time the evaluation of the experiment was performed.

\section{Evaluated variables and statistical analysis}

In both experiments, the percentage of survival, percentage of mini-cuttings that had calluses and percentage of rooted mini-cuttings were evaluated. In the experiment with different concentrations of growth regulator in low rooting clones, the number of roots was also evaluate, a parameter that was not analyzed in the previous experiment, since the seedlings from this experiment were destined to the field planting. The count of the number of roots implies in the disintegration of the substrate, causing serious damages to the roots of the cuttings. To evaluate the number of roots, the complete removal of the substrate, subsequent root washing and counting of all roots were performed visually.

Surviving mini-cuttings were those that had live wood, old leaves or young shoots, rooted or not. For calluses, the mini-cuttings were considered alive, with undifferentiated cell mass at the base, rooted or not. The percentage of rooting was considered on the total, not only on the surviving. It was considered as rooted minicuttings with induction of root origin of at least $2 \mathrm{~mm}$ in length.

After checking the normality of the data by means of the Kolmogorov-Smirnov and homogeneity by the Bartlett test, the analysis of variance was performed. When necessary, the data were transform by the function ( $\mathrm{x}$ $+0.5)^{0.5}$ and the means were compared by the Scott-Knott test, at $5 \%$ probability.

\section{RESULTS}

In the first experiment, evaluating the rooting of mini-cuttings of different clones, there was a significant difference between the three variables analyzed (Table 1). Mean survival between clones was high, almost 95\%. Only four clones showed mini-cutting survival less than $90 \%$. Regarding callus formation, with the exception of clones A116 and A140, all others presented more than $80 \%$.

The rooting, the main variable observed when working with the mini-cutting technique, showed great variation among the clones. Some clones (A113, A115, A127 and A136) showed 100\% or very close rooting. Half of the evaluated clones (eight) showed rooting indices between $66.7 \%$ and $87.8 \%$, and only four of them (A100, A117, A126 and A138) presented rooting less than 50\%.

For the four clones that obtained rooting less than $50 \%$ in the first experiment, after being submitted to IBA application, there was a significant effect of the clone factor for survival (\%) and callus formation (Table 2). For clone root number and IBA concentrations, there was no significant effect on the three variables analyzed.

FLORESTA, Curitiba, PR, v. 50, n. 2, p. 1279 - 1286, abr/jun 2020.

Pereira, M. O. et.al.

ISSN eletrônico 1982-4688 
The survival of mini-cuttings varied between clones, ranging from $88.1 \%$ (A138) to $99.4 \%$ (A126). Callus formation was also high for most clones, remaining close to $90 \%$, except for A117, which presented lower calogenic formation. The number of roots presented an average of 3.5, showing no significant difference between clones and concentrations of IBA used.

In relation to the rooting percentage, there was an interaction between the clones and the IBA concentrations. For all clones, the quadratic function presented a better adjustment (Figure 1). For clones A126, A138 and A100, rooting without growth regulator was less than $25 \%$, with significant elevation when 1,000 mg L-1 of IBA was used. Clone A117 was the only one to present rooting near $40 \%$ without the use of IBA and to maintain rooting near this value with the use of growth regulator.

Tabela 1. Sobrevivência (\%), formação de calos (\%) e enraizamento (\%) de miniestacas de Sequoia sempervirens obtidas de diferentes clones.

Table 1. Survival (\%), callus formation (\%) and rooting in the mini-cuttings of Sequoia sempervirens obtained from different clones.

\begin{tabular}{cccc}
\hline \multirow{2}{*}{ Clone } & & Variable & \\
\cline { 2 - 4 } & Survival $(\%)$ & Callus $(\%)$ & Rooting $(\%)$ \\
A136 & $100.0 \mathrm{a} *$ & $98.1 \mathrm{a}$ \\
A133 & $100.0 \mathrm{a}$ & $90.3 \mathrm{a}$ & $84.1 \mathrm{~b}$ \\
A131 & $100.0 \mathrm{a}$ & $100.0 \mathrm{a}$ & $66.7 \mathrm{~b}$ \\
A138 & $100.0 \mathrm{a}$ & $88.3 \mathrm{a}$ & $22.8 \mathrm{~d}$ \\
A100 & $100.0 \mathrm{a}$ & $87.9 \mathrm{a}$ & $36.9 \mathrm{c}$ \\
A127 & $98.7 \mathrm{a}$ & $82.0 \mathrm{~b}$ & $98.7 \mathrm{a}$ \\
A115 & $98.4 \mathrm{a}$ & $100.0 \mathrm{a}$ & $95.4 \mathrm{a}$ \\
A113 & $98.1 \mathrm{a}$ & $95.0 \mathrm{a}$ & $100.0 \mathrm{a}$ \\
A227 & $95.6 \mathrm{a}$ & $91.0 \mathrm{a}$ & $87.8 \mathrm{~b}$ \\
A130 & $97.2 \mathrm{a}$ & $86.7 \mathrm{a}$ & $77.5 \mathrm{~b}$ \\
A116 & $96.4 \mathrm{a}$ & $75.0 \mathrm{~b}$ & $84.2 \mathrm{~b}$ \\
A135 & $95.2 \mathrm{a}$ & $79.5 \mathrm{~b}$ \\
A117 & $88.7 \mathrm{~b}$ & $98.0 \mathrm{a}$ & $48.7 \mathrm{c}$ \\
A140 & $86.5 \mathrm{~b}$ & $78.7 \mathrm{~b}$ & $86.0 \mathrm{~b}$ \\
A228 & $86.4 \mathrm{~b}$ & $85.1 \mathrm{~b}$ & $86.4 \mathrm{~b}$ \\
A126 & $82.1 \mathrm{~b}$ & $83.5 \mathrm{~b}$ & $39.8 \mathrm{c}$ \\
\hline -valor & $<0.001$ & 0.035 & $<0.001$ \\
CV\% & 19.2 & 24.4 & 22.1 \\
Overall average & 94.4 & 88.6 & 73.3 \\
\hline
\end{tabular}

* Means followed by the same lowercase letter in the column do not differ by Scott-Knott's test, $5 \%$ error probability.

Tabela 2. Sobrevivência (\%), formação de calos (\%) e número de raízes em miniestacas de Sequoia sempervirens em função dos diferentes clones e concentrações de AIB.

Table 2. Survival (\%), callus formation (\%) and number of roots in Sequoia sempervirens mini-cuttings according to the different clones and IBA concentrations.

\begin{tabular}{clccc}
\hline & & Survival (\%) & Callus (\%) & Number of roots \\
\hline \multirow{5}{*}{ CLONE } & A100 & $92.1 \mathrm{~b}^{*}$ & $89.4 \mathrm{a}^{*}$ & $3.8^{\mathrm{ns}}$ \\
& A117 & $92.4 \mathrm{~b}$ & $76.5 \mathrm{~b}$ & 3.7 \\
& A126 & $99.4 \mathrm{a}$ & $92.3 \mathrm{a}$ & 3.2 \\
& A138 & $88.1 \mathrm{~b}$ & $92.5 \mathrm{a}$ & 3.4 \\
\hline \multirow{5}{*}{ IBA $\left(\mathrm{mg} \mathrm{L}^{-1}\right)$} & 0 & $94.2^{\mathrm{ns}}$ & $92.5^{\mathrm{ns}}$ & $2.9^{\mathrm{ns}}$ \\
& 1,000 & 92.7 & 84.0 & 3.3 \\
& 2,000 & 94.3 & 85.0 & 3.7 \\
\hline
\end{tabular}

* Means followed by the same lowercase letter in the column do not differ by Scott-Knott's test, $5 \%$ error probability. ${ }^{\text {ns }}$ - Not significant at $5 \%$ probability of error. 
For clones A126, A117 and A100, the concentration indicated by the fit of the equations is close to 1,500 $\mathrm{mg} \mathrm{L}^{-1}$ of IBA. Only for clone A138 that the maximum response can be obtain with concentration, close to 2,000 $\mathrm{mg} \mathrm{L}^{-1}$. For all clones, the use of the highest concentration of IBA (2000 $\left.\mathrm{mg} \mathrm{L}^{-1}\right)$ presented similar results.

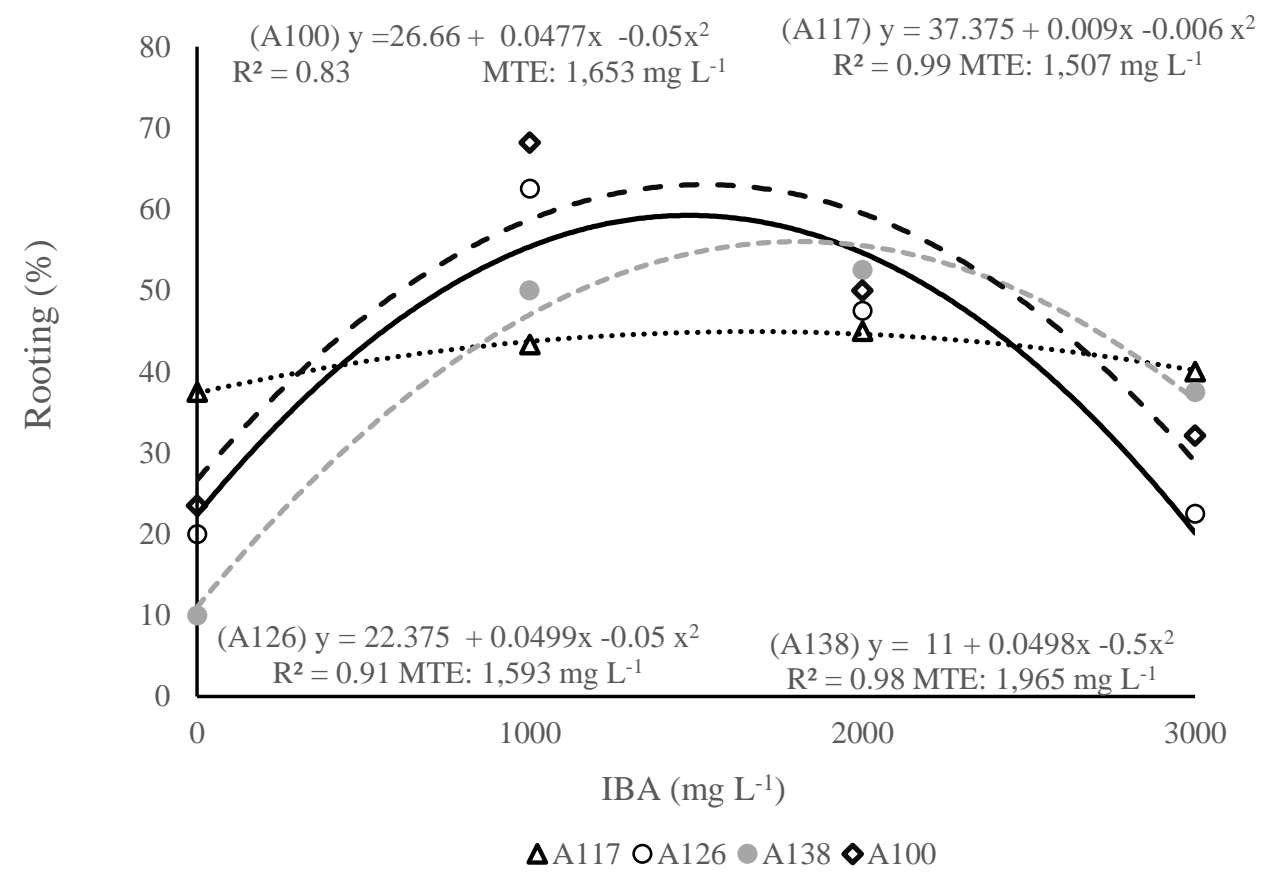

Figura 1. Enraizamento de miniestaquia de Sequoia sempervirens (Clones: A100, A117, A126 e A138) em diferentes concentrações de AIB.

Figure 1. Mini-cutting rooting of Sequoia sempervirens (Clones: A100, A117, A126 and A138) at different IBA concentrations.

\section{DISCUSSION}

The good survival results of the mini-cuttings for the 16 clones demonstrate an adequate control of temperature and, especially, humidity provided in the rooting environment (mini-tunnel) during the conduction of the experiment, and it is indispensable that it presents adequate conditions for the maintenance of mini-cuttings (STUEPP et al., 2013). In addition, the very ability of the mini-cuttings of the species to survive, resembling other vegetative propagation species such as Eucalyptus (BRONDANI et al., 2010).

Callus formation in sequoia mini-cuttings is common (NAVROSKI et al., 2015). Some clones present all of these with the presence of calogenic structures, some of which are less well formerd, such as clone A116 (75\%). The roots of the sequoia mini-cuttings, as well as other genus of conifers (Cryptomeria, Larix, Podocarpus, Picea e Taxodium) usually have roots arising from external calogenic tissues (HARTMANN et al., 2011). According to the same authors, in some species the formation of callus is a precursor of the formation of adventitious roots. However, calogenesis has been reported as an obstacle to the rooting of propagules of various forest species (SINGH; ANSARI, 2014).

In relation to rooting, a high variation was find in the results, with good indexes for most clones, with only four of them with averages below $50 \%$. The low rate of rooted mini-cuttings may be relate to the recalcitrance of these four clones. Thus, indirect selection may be unfavorable for growth or adaptive characteristics due to the propagation of specific genotypes (more likely to be mini-cutting), resulting in loss of clones in the selection process (OLIVEIRA et al., 2015).

For the great majority of the clones, the rooting indexes were superior to $80 \%$ and can be consider as very promising for the species, mainly because it is a material only reinvigorated by the technique of girdling in the field trees and one pruning in the clonal mini-garden. Work developed with Sequoia sempervirens by Luna (2008) showed inferior rooting to the present study, with values between 30 to $35 \%$. Similar rooting (80\%) was achieved only in the work of Navroski et al. (2015). All the works referenced made use of cuttings for the rooting, and no reports of works were done using clonal mini-garden, with later use of mini-cutting in the production of cuttings of the species.

FLORESTA, Curitiba, PR, v. 50, n. 2, p. 1279 - 1286, abr/jun 2020.

Pereira, M. O. et.al.

ISSN eletrônico 1982-4688 
This great difference in rooting between clones reveals possible genotypic effects for this trait. Dantas et al. (2016) comments that the genetic component is one of the factors that most influence the rooting, having a greater or lesser natural ability to form roots between the different clones.

In a study with Eucalyptus cloeziana, propagated by mini-cutting, there was the indication of an expressive genetic control in rooting (OLIVEIRA et al., 2015). The same authors inferred that there were experimental rigor and good reliability in the prediction of genotypic values, with the possibility of identifying superior clones for adventitious rooting. Still according to these authors, the presence of considerable variation in rooting between clones indicates the possibility of practicing selection among sequoia clones propagated through mini-cutting, and it is possible to obtain significant genetic gains.

The lack of work related to the selection of superior genotypes for rooting in a forest improvement program is probably a consequence of the elimination of productive genotypes to other characteristics of interest. The selection of rooting of cuttings/mini-cuttings occurs naturally in nurseries, since recalcitrant genotypes/clones for rooting was discarded (OLIVEIRA et al., 2015), especially in species already cultivated. However, for species still in initial breeding trials, such as sequoia, the disposal of these less rooting materials should not be done, since clones with difficulty in being propagated by vegetative means may have good silviculture characteristics in the field, making them interesting long-term.

Concerning the application of IBA to clones with roots of less than $50 \%$, observed in the first experiment, a difference was again observed between the clones for survival and callus formation in the mini-cuttings. In relation to rooting, the effect of the exogenous application of auxin on the four clones was observed. Without the use of IBA, three of the four clones showed low root formation $(<25 \%)$. Already with the use of $1,000 \mathrm{mg} \mathrm{L}^{-1} \mathrm{of}$ IBA there was increased in rooting, reaching almost $70 \%$ for clone A100.

Adventitious root formation is a demanding process of high energy, involving cell division, in which the predetermined cells move from their morphogenetic pathway to act as mother cells for the beginnings of the root; therefore, need hormonal stimuli for root initiation (GEHLOT et al., 2014). This efficiency for root induction depends on the presence of endogenous auxin levels, which may vary according to age, propagule position and genotype. When the responsible factor is the genotype or clone, one can make use of exogenous growth regulators, especially in cases of superior clones (WENDLING et al., 2014).

The rooting of cuttings/mini-cuttings was especially controlled by endogenous levels of plant regulators, mainly auxins (LI et al., 2009). As noted in some clones in the present experiment, exogenous auxin applications may increase rooting percentage due to its ability to act on plant tissues located near the excision region (ZHU et al., 2010), and may be related to concentrations and time of immersion (WENDLING et al., 2010). Therefore, the application of IBA acts as a metabolizing agent and signal for the induction of rooting. During external contact with the cell, IBA induces changes in the metabolism of enzymes, carbohydrates, RNA, DNA and proteins. These changes in the rooting region may inhibit or promote adventitious root regeneration, especially during cell division and differentiation (KOMATSU et al., 2011).

Generally, the concentrations considered optimal for root formation are very particular to each situation (BRONDANI et al., 2010). This fact was observed in the present study, where the clones presented different behaviors regarding the need to use IBA (Figure 1). Almeida et al. (2007), testing concentrations of 0 to $6000 \mathrm{mg}$ $\mathrm{L}^{-1}$ of IBA observed that some clones of Eucalyptus cloeziana, a species considered difficult to vegetative propagation, presented higher rhizogenic potential of mini-cuttings only when treated with the highest concentrations of the plant regulator. The application of plant regulators is subject to the physiological and genetic conditions of the matrix plant and may not result in a significant increase in rooting, as was observed for clone A117 in this study.

The application of auxin induces the rooting in species of conifers as Pinus elliottii var. elliottii $x P$. caribaea var. hondurensis (HUNT et al., 2011), Pseudotsuga menziesii (COPES; MANDEL, 2000) and Pinus radiata (RICCI et al., 2008), among others. In general, auxin may be more beneficial in species or clones difficult to root or with less predisposition to rooting (HUNT et al., 2011), as observed in the present study. However, in many cases, auxin does not provide an improvement in rooting (DIAS et al., 2012), showing that some species have a natural ability to rooting mini-cuttings, not justifying the application of indolebutyric acid for the induction of adventitious roots.

Above $2,000 \mathrm{mg} \mathrm{L}^{-1}$, the application of IBA caused a reduction in the rooting of the mini-cuttings. This is because the exogenous auxin has exceeded its maximum utilization point, from which point it becomes inhibitory (POP et al., 2011). In this sense, Hartmann et al. (2011) states that when applying plant regulators, there is a stimulating effect on the induction of roots, but this stimulus reached a maximum point, from which it becomes inhibitory. A similar result, with a reduction in rooting from an ideal concentration, has also been report in Sequoia sempervirens (NAVROSKI et al., 2015) and other species such as Taxus wallichiana (KAUL, 2008) and Handroanthus heptaphyllus (OLIVEIRA et al., 2015). 


\section{CONCLUSIONS}

- There is wide variation in mini-cutting rooting among the sequoia clones evaluated.

- The survival and callus formation exhibit less variation, presenting an average of close to $90 \%$.

- Clones that presented rooting less than $50 \%$ in the first experiment and were submitted to application with IBA reported varied responses, but with improved in the rooting.

\section{ACKNOWLEDGMENTS}

The authors would like to thank Coordenação de Aperfeiçoamento de Pessoal de Nível Superior (CAPES) and Conselho Nacional de Desenvolvimento Científico e Tecnológico (CNPq) for the scholarship awarded.

\section{REFERENCES}

ALMEIDA, F. D.; XAVIER, A.; DIAS, J. M. M.; PAIVA, H. N. Eficiência das auxinas (AIB e ANA) no enraizamento de miniestacas de clones de Eucalyptus cloeziana F. Muell. Revista Árvore, Viçosa, v. 31, n. 3, p. 455-463, 2007.

BRONDANI, G.E.; GROSSI, F.; WENDLING, I.; DUTRA, L. F.; ARAUJO, M. Aplicação de IBA para o enraizamento de miniestacas de Eucalyptus benthamii Maiden \& Cambage x Eucalyptus dunnii Maiden. Acta Scientiarum Agronomy, Maringá, v.32, n.4, p.667-674, 2010.

COPES, D. L.; MANDEL, N. L. Effects of IBA and NAA treatments on rooting Douglas-fir stem cuttings. New Forests, West Lafayette, v. 20, n. 4, p. 249-257, 2000.

DANTAS, A. K., MAJADA, J.; DANTAS, F. K.; DELATORRE, C.; GRANDA, V.; LALLEJO, P.; FEITO, I. Enraizamento de miniestacas de clones híbridos de Castanea sativa Mill. Revista Árvore, Viçosa, v. 40, n. 3, p. 465-475, 2016.

DIAS, P. C.; XAVIER, A.; OLIVEIRA, L. S. de; PAIVA, H. N. de; CORREIA, A. C. G. Propagação vegetativa de progênies de meios-irmãos de angico-vermelho (Anadenanthera macrocarpa (Benth) Brenan) por miniestaquia. Revista Árvore, Viçosa, v. 36, n. 3, p. 389-399, 2012.

GEHLOT, A.; GUPTA, R. K.; TRIPATHI, A.; ARYA I. D.; ARYA, S. Vegetative propagation of Azadirachta indica: effect of auxin and rooting media on adventitious root induction in mini-cuttings. Advance in Forestry Science, Cuiabá, v. 1, n. 1, p. 1-9, 2014.

HARTMANN, H. T.; KESTER, D. E.; DAVIES JR, F. T.; GENEVE, R. L. Hartmann and Kester's Plant propagation: principles and practices. 8. ed. New Jersey: Prentice Hall, 2011.915 p.

HUNT, M. A.; TRUEMAN, S. J.; RASMUSSEN, A. Indole-3-butyric acid accelerates adventitious root formation and impedes shoot growth of Pinus elliottii var. elliottii $x$ P. caribaea var. hondurensis cuttings. New Forests, West Lafayette, v. 41, n. 3, p. 349-360, 2011.

KAUL, K., Variation in rooting behaviour of stem cuttings in relation to their origin in Taxus wallichiana Zucc., New Forests, West Lafayette, v. 36, p. 217-224, 2008.

KOMATSU, Y. H.; BATAGIN-PIOTTO, K. D.; BRONDANI, G. E.; GONÇALVES, A. N.; ALMEIDA, M. In vitro morphogenic response of leaf sheath of Phyllostachys bambusoides. Journal of Forestry Research, Harbin, v. 22, n. 2, p. 209-215, 2011.

KORBAN, S. S.; SUL, I. - W. Micropropagation of coast redwood (Sequoia sempervirens) In: JAIN, S. M.; HÄGGMAN, H. Protocols for micropropagation of woody trees and fruits. Springer, Berlin; 2007.

LI, S. W.; XUE, L.; XU, S.; FENG, H.; AN, L. Mediators, genes and signaling in adventitious rooting. The Botanical Review, New York, v. 75, n. 2, p. 230-247, 2009.

LUNA, T. Vegetative Propagation of Coastal Redwood (Sequoia sempervirens (Lamb. ex D. Don) Endl.). Native Plants Journal, Washington, v. 9, n. 1, p. 25 - 28. 2008.

NAVROSKI, M. C.; PEREIRA, M. O.; HESS, A. F.; SILVESTRE, R.; ÂNGELO, A. C.; FAZZINI, A. J.; ALVARENGA, A. A. Resgate e propagação vegetativa de Sequoia sempervirens. Floresta, Curitiba, v. 45, n. 2, p. $383-392,2015$. 
OLIVEIRA, T. P. F.; BARROSO, D. G.; LAMÔNICA; K. R.; CARVALHO; G. C. M. W. Aplicação de AIB e tipo de miniestacas na produção de mudas de Handroanthus heptaphyllus Mattos. Ciência Florestal, Santa Maria, v. 26 , n. 1 , p. $313-320,2016$.

OLIVEIRA et al. Efeito do ácido indol-3-butírico (AIB) no enraizamento de miniestacas de ipê-roxo (Handroanthus heptaphyllus Mattos). Ciência Florestal, Santa Maria, v. 25, n. 4, p. 1043-1051, 2015.

OLIVEIRA, Y.; AlCANTARA, G. B.; GUEDES, I.; PINTO, F.; QUOIRIN, M.; BIASI, L. A. Substratos, concentrações de ácido indolbutírico e tipos de miniestacas no enraizamento de melaleuca (Melaleuca alternifólia Cheel). Revista Brasileira de Plantas Medicinais, Paulinia, v. 14, n. 4, p. 611-616, 2012.

OLSON, D. F.; ROY, D. F.; WALTERS, G. A. Sequoia sempervirens (D. Don) Endl, redwood. In BURNS, R. M.; HONKALA, B. H. [eds.], Silvics of North America. U.S. Department of Agriculture, Agricultural Handbook, v. 1, p. $541-551,1990$.

POP, T.I., PAMFIL, D., BELLINI, C. Auxin Control in the Formation of Adventitious Roots. Notulae Botanicae. Horti Agrobotanici Cluj-Napoca, Cluj-Napoca, v. 39, n. 307-316, 2011.

RICCI, A.; ROLLI, E.; DRAMIS, L.; DIAZ-SALA, C. N. N'-bis-(2, 3-Methylenedioxyphenyl) urea and N, N'bis (3, 4-Methylenedioxyphenyl) urea enhance adventitious rooting in Pinus radiata and affect expression of genes induced during adventitious rooting in the presence of exogenous auxin. Plant Science, Amsterdam, v. 175, p. 356-363. 2008.

SINGH, S.; ANSARI, S. A. Callus formation impedes adventitious rhizogenesis in air layers of broadleaved tree species. Annals of Forest Research, Paris, v. 57, n. 1, p. 47-54, 2014.

STUEPP, C.A.; PEREIRA, G.P.; ZEM, L.M.; PEÑA, M.L.; BUENO, P.M. C.; SPADER, V.; ZUFFELLATORAIBS, K.C.; ROSA, G.M. Enraizamento de melaleuca: influência da altura de coleta das estacas e aplicação de AIB. Colloquium Agrariae, Presidente Prudente, v.9, p.01-09, 2013.

WENDLING, I.; BRONDANI, G. E.; DUTRA, L. F.; HANSEL, F. A. Mini-cuttings technique: a new ex vitro method for clonal propagation of sweetgum. New Forests, West Lafayette, v. 39, n. 3, p. 343-353. 2010.

WENDLING, I.; TRUEMAN, S. J.; XAVIER, A. Maturation and related aspects in clonal forestry-part II: reinvigoration, revitalization and juvenility maintenance. New Forests, West Lafayette, v.1, p.1-14, 2014.

ZHU, X.Y.; CHAI, S. J.; CHEN, L. P.; ZHANG, M. F.; YU, J. Q. Induction and origin of adventitious roots from chimeras of Brassica juncea and Brassica oleracea. Plant Cell, Tissue and Organ Culture, Rockville, v. 101, n. 3, p. 287-294, 2010. 